\title{
CORRESPONDENCE
}

\section{Fear of Enlightenment}

SrR,-We were rather surprised by the contents of your editorial "Fear of Enlightenment" (Nature, 228, 1013; 1970), more especially by its title. It seems to us that it misinterprets and presents a biased view of our article especially for those of your readers who have not read the original in the October 1970 issue of the Scientific American, entitled "Intelligence and Race". It is unfortunately all too easy to misinterpret or place the wrong emphasis on a statement taken out of its proper context. Perhaps we were at fault in assuming that a scientifically oriented audience would interpret our comments as they were meant to be, even if briefly stated, rather than as so often happens in everyday life, exaggerate our views to an extent which was clearly neither implied nor intended. We have nowhere in our article argued, as you state, for a "moratorium" on research on such questions as the genetic component of the race IQ difference, or that these questions "should be put into cold storage". Our remarks were clearly not meant as a proposal to bar well founded research in these areas.

As we stated in our article, its aim was to review, mainly for the non-geneticist, the meaning of race and IQ and the approaches to determining the extent to which IQ is inherited, in the hope that this could act as a basis for the objective assessment of the evidence for a genetic component in race and class $1 Q$ differences. One of our major conclusions was that, though we do not by any means exclude the possibility that there could be a genetic component in the mean difference in IQ between races, we believe that there is no evidence against the notion that environmental factors, many of which doubtless remain to be discovered, could explain essentially all the differences in IQ between blacks and white. It is our view that the only conclusive approach applicable to the study of the genetic component of the IQ differences between the races is that of working with black children adopted into white homes and vice versa, and that it is most unlikely that such studies could be done in a reasonably controlled way at the present time especially in the United States.

We tried, within the limits imposed by the audience which we were addressing, to give the scientific basis for our belief that the problem of the genetic contribution to racial differences in IQ is not solved and is not easily soluble by the techniques available today. This point is not even mentioned briefiy in your leading article, but is apparently simply dismissed with a vague expression of the opposite belief, namely, that the solution is somehow at hand. The peculiar remark is also added that we should have more confidence "that a proper investigation would produce the result they desire". This seems a strange way of discussing scientific methods and conclusions. Should you not have countered scientific argument with scientific argument? The only example given, namely, the disappearance of the australopithecines, seems a weak one indeed. Moreover, the worry expressed in your editorial that miscegenation may destroy the chance to carry out such investigations cannot be taken too seriously if one considers the relevant facts and figures, which show how far ahead this possibility still lies.
We expect that the problem will be soluble and will be solved well before the time at which complete miscegenation has taken place.

We should, assuredly, be among the first to welcome that break-through in our scientific understanding of the basis of intellectual ability which might lead, in some at present unknown way, to obtaining precise answers to these very difficult questions. As is well known, however, such break-throughs rarely, if ever, come from a massive investment of funds in any particular line of basic scientific research.

Professor Shockley has repeatedly asked for a major expenditure of funds directed specifically at finding the answer to the question of a genetic component to the race IQ difference and other, in our view, similarly at present unanswerable questions, because of their practical importance. He has, in fact, drawn an analogy with the United States man in space programme (see forthcoming correspondence in the Scientific American, January, 1971). Apart from the fact that we can see no way in which such information could or should be used in practice, we believe that at the present time such a major appropriation of public funds would be completely misdirected and could achieve nothing positive. When we talk of not "... particularly encouraging the use of public funds ..." we are referring specifically to this kind of directed effort which occurs at many levels through the earmarking of public funds for particular programmes of research in the basic as well as in the applied sciences. We are not afraid of taking the view of "stout hearted liberalism" you commend to us and which we

\section{Continued from page 21}

${ }^{68}$ Athavale, R. N., Radhakrishnamurty, C., and Sahasrabudhe, P. W., Geophys. J., 7, 304 (1963).

${ }^{69}$ Boesen, R., Irving, E., and Robertson, W. A., J. Proc. Roy. Soc., $N S W, 94,227$ (1961).

${ }^{70}$ Irving, E., J. Geophys. Res., 68, 2283 (1963).

${ }^{71}$ Le Pichon, X., and Heirtzler, J. R., J. Geophys. Res., 73, 2101 (1968).

72 Turnbull, G., Arctic, 12, 151 (1959).

${ }^{73}$ Bull, C., Irving, E., and Willis, I., Geophys. J., 6, 320 (1962).

74 Briden, J. C., and Oliver, R. L., New Zeal. J. Geol. Geophys., 6, 388 (1963).

75 Opdyke, N. D., J. Geophys, Res., 66, 1941 (1961).

${ }^{76}$ Irving, E., and Banks, M. R., J. Geophys. Res., 66, 1935 (1961).

77 Beck, M. E., J. Geophys. Res., 70, 45 (1965).

${ }_{78}$ Larochelle, A., and Wanless, R. K., J. Geophys. Res., 71, 4949 (1966).

${ }^{79}$ Larochelle, A., Geol. Surv. Canada: Paper 67-39, 7 (1967).

${ }^{80}$ Robertson, W. A., Canad. J. Earth Sci., 4, 641 (1967)

81. Carmichael, C. M., and Palmer, H. C., J. Geophys. Res., 73, 2811 (1968).

${ }^{82}$ Larochelle, A., and Currie, R. G., J. Geophys. Res., 72, 4163 (1967).

${ }^{83}$ de Boer, J., J. Geophys. Res., 72, 2237 (1967).

84 Gough, D. I., and Brock, A., J. Geophys. Res., 69, 2489 (1964)

${ }^{85}$ Opdyke, N. D., J. Geophys. Res., 69, 2495 (1964).

${ }^{86}$ Creer, K. M., Embleton, B. J. J., and Valencio, D. A., Earth Planet. Sci. Lett. (in the press)
${ }^{87}$ Briden, J. C., J. Geophys. Res., 73, 725 (1968).

${ }^{88}$ Brock, A., Nature, 216, 359 (1957).

${ }^{89}$ McElhinny, M. W., and Opdyke, N. D., J. Geophys. Res., 73, 689 (1968).

${ }^{90}$ Creer, K. M., Nature, 203, 4950 (1964).

${ }_{91}$ Morgan, W. J., J. Geophys. Res., 73, 1959 (1968).

${ }_{92}$ Verma, R. K., and Bhalla, M. S., J. Geophys. Res., 73, 703 (1968).

${ }^{93}$ Briden, J. C., Geophys. J., 11, 267 (1966).

94 Chamalaun, F. H., Earth Planet. Sci. Lett., 3, 439 (1968).

95 Irving, E., and Parry, L. G., Geophys. J., 7, 395 (1963).

${ }^{96}$ Robertson, W. A., Pure Appl. Geophys., 59, 93 (1964).

97 Wensink, H., Palaeogeog., Palaeoclimat., Palaeoecol., 5, 323 (1968).

${ }^{98}$ Nagata, T., and Yama-ai, M., Antarctic Rec., 11, 954 (1961).

${ }^{99}$ Wensink, H., and Klootwijk, C. T., Earth Planet. Sci. Lett., 4, 191 (1968).

${ }^{100}$ Helsley, C. E., Trans. Amer. Geophys. Union, 44, 33 (1965).

101 Thomas, D. H., thesis, Newcastle upon Tyne (1969).

${ }^{102}$ Kobayashi, T., and Shikama, T., in Descriptive Palaeoclimatology (edit, by Nairn, A. E. M.) (Interscience, New York, 1961).

${ }^{103}$ Drake, C. L., Ewing, J. I., and Stockard, H., Canad. J. Earth Sci., 5, 993 (1968)

${ }_{104}$ Reyment, R. A., Nature, 224, 137 (1969).

${ }^{105}$ Larson, O., and Moller, J., Canad. J. Earth Sci., 5, 683 (1968)

106 Watt, S. W., Canad. J. Earth Sci., 6, 1320 (1969).

${ }^{107}$ Birkelund, T., Bull. Grønland Geol. Unders., 56 (1965). 
believe was properly represented in our article. It is with this view in mind that we believe that, rather than supporting the sort of programme which Professor Shockley seems to be advocating, the kind of effort put by the United States into getting a man on the Moon would be better directed to solving social and economic problems, racial or otherwise, in terms of the environment.

Yours faithfully,

\section{WALTER F. BODMER}

Genetics Laboratory,

Department of Biochemistry, South Parks Road, Oxford

Luca L. Cavalli-Sforza

Istituto di Genetica,

Università di Pavia,

Via Sant Epifanio 14,

Pavia, Italy

If the statement in the article in Scientific American that "in the present racial climate of the United States, studies on racial differences in IQ, however well intentioned, could easily be misinterpreted as a form of racism and lead to an unnecessary accentuation of racial tensions..." and the conclusion that "we do not see any point in particularly encouraging the use of public funds for their support" were intended merely as comments on proposals such as that of Professor W. Shockley (complained of in Nature, 228, 1013; 1970, but not mentioned in the Scientific American), Professors Bodmer and Cavalli-Sforza might have helped their readers by saying so explicitly. Editor, Nature.

Sir,--In your recent editorial comment (Nature, 228, 1013 ; 1970) on the suggestion by Professors Bodmer and CavalliSforza that there be a moratorium on public research projects dealing with the etiology of observed differences in IQ scores between races, you ignore one of their main points.

It is a fact that there are many illiberal elements in American society who would be delighted to quote or misquote any socalled objective research in support of their viewpoint. I think the present state of knowledge in this field is such that virtually any research carried out is likely ammunition for the illiberal view, however specious their arguments may be.

Consider, for example, my own subjective impression that the educated professional blacks of my former acquaintance were not as intelligent, overall, as their white counterparts. I formulated this viewpoint while a student of psychology in the United States some 13 years ago, and because I was and am of liberal conviction, I concluded that my impression was caused by unconscious prejudice that I had picked up in some way. Consequently, I never voiced my impression, and maintained stoutly that there surely was no innate difference (intellectually) between whites and blacks. On moving to Britain some eight years ago, I was soon struck by the reverse impression that educated professional blacks in Britain were, if anything, more intelligent than their white counterparts.

I now believe that my contrary impressions could have a kernel of truth. The American black is descended mainly from the former slave population, and it must be remembered that slaves obtained from Africa were often captured and sold in a trade which lasted for many decades. British blacks of my acquaintance seem to be mainly from Africa rather than descendants of slaves. Could not the selection factors involved in the establishment of the American black population have ensured that their gene pool differed from the blacks remaining in Africa? Surely the blacks who were captured for slaves must have tended to be different from those who escaped or, indeed, from some who acted as captors. High intelligence would undoubtedly help escape efforts.

If my observation is true, the best designed studies carried out in America will only support the illiberal contentions. British blacks cannot be used as controls because of cultural and language differences. Can anyone propose a methodology which would resolve all of these difficulties? In the absence of an adequate methodology, can we justify such research when we are aware of the immoral use that is sometimes made of the results?

\section{Yours faithfully,}

\section{A. E. Hendrickson}

Institute of Psychiatry,

De Crespigny Park,

Denmark Hill,

London SE5

\section{Information Explosion}

SIR,-In a review (Nature, 228, 966; 1970), Professor F. A. Jenner refers to "The more than exponential increase in scientific information". There has indeed been some increase, but it is far from being exponential, let alone "more than exponential". There has been a great increase in numbers of those involved in most kinds of research, and a phenomenal increase in expenditure, but the amount of information produced, if by information we mean scientific papers describing original work, has been very disappointing. The most noteworthy change in the past 30 years has been the increasing sterility of research workers, and the way in which so much money has been spent with little to show for that expenditure.

Yours faithfully,

K. Mellanby

The Athenaeum,

London $S W 1$

\section{Obituary}

\section{Professor G. Hübscher}

GEORG Hubscher, foundation professor of biochemistry in the new Medical School of the University of Nottingham, died suddenly after suffering a heart attack on November 3, 1970.

He was born in Berlin and studied medicine both at the Humboldt University and the Phillips University in Marburg an der Lahn. His interest in biochemistry was soon apparent from his work on the preparation and properties of heart muscle cytochrome c in Professor Kiese's laboratory in the Pharmacological Institute at Marburg. The results of this research were accepted in 1953 in fulfilment of the requirements for the MD degree. He completed his medical training at the St Elizabeth Hospital, New Jersey. Georg Hübscher then joined D. E. Green's department at the Institute for Enzyme Research in Madison in 1954 where his interest in enzymology was fostered by studies on the purification and mode of action of uricase. In 1956 he came to England to work in Professor A. C. Frazer's Department of Medical Biochemistry and Pharmacology in Birmingham where in 1964 he became senior lecturer and later reader. He found scope to develop a dynamic teaching programme in intermediary metabolism and enzymology and to gather together a thriving research team to study the biosynthesis of phospholipids and other glycerides in liver and intestinal mucosa. He soon established himself as an authority in these subjects and was awarded the degrees of PhD in 1957 and DSc in 1964. Among his notable contributions to the field of lipid metabolism were the discovery (with B. Clark) of the pathway of resynthesis of triglycerides in the mucosa of the small intestine by direct esterification of monoglycerides and the isolation of phosphatidic acid from ox liver. More recently, his interests were concerned with pathways of phosphatidic acid and glyceride biosynthesis in microsomal and mitochondrial preparations of rat liver and with the short and long term control of the levels of glycolytic enzymes in the mucosa of the small intestine. He was a member of the editorial board of Gut. In 1967, he was appointed foundation professor in the new Medical School at Nottingham. He threw himself with zeal into the tasks of establishing a new and active department.

The tragic death of Professor Hübscher at such an early age has meant a great loss to the new Medical School, whose first undergraduates had arrived only a few weeks before. A man of humanity, integrity and energy, he would have had much to offer future generations of medical and science students at Nottingham. 